\begin{tabular}{|c|c|}
\hline Journal STAND: Sports and Development \\
unipa Sumalaya & $\mathrm{http} / /$ jurnal.unipasby.ac.id/index.php/stand/about/submissions \\
\hline
\end{tabular}

\title{
PENINGKATAN KEMAMPUAN PASSING BOLA MELALUI LATIHAN KUCING-KUCINGAN PADA EKSTRAKURIKULER FUTSAL DI MADRASAH ALIYAH NEGERI 1 JOMBANG
}

\begin{tabular}{l} 
\\
\\
\hline Artikel Info \\
\hline Koresponden penulis: \\
Akmal Istighfar \\
Email. \\
akmalistighfar@gmail.com \\
$\square$ Diterima 22 April 2020 \\
$\square$ Direview 12 Mei 2020 \\
$\square$ Disetujui 13 Mei 2020 \\
$\square$ Dipublikasi 27 Mei 2020
\end{tabular}

Kata Kunci:

Passing, Futsal, Latiban Kucing kucingan, ekstrakurikuler

Keywords:

Passing, Futsal, Training, Rondo, extracurricular

\author{
Akmal Istighfar ${ }^{1}$ \\ Madrasah Aliyah Negeri 1 Jombang \\ akmalistighfar@gmail.com
}

\begin{abstract}
Abstrak
Futsal merupakan salah satu ekstrakurikuler yang cukup digemari. Hal ini sangat membantu dalam memfasilitasi dan melatih keterampilan siswa dalam bermain futsal di luar jam pelajaran. Menurut hasil observasi mengenai keadaan para pemain pada ekstrakurikuler futsal, banyak pemain yang masih memiliki kemampuan kurang baik dalam melakukan passing bola, sehingga ketika melakukan permainan futsal masih banyak siswa yang mengalami kesulitan untuk dapat bermain dengan baik. Dalam penelitian ini jenis penelitian ini termasuk jenis penelitian eksperimen. Penelitian eksperimen ini menggunakan desain "Pre-test dan Post-test". Instrumen dalam penelitian ini menggunakan alat ukur tes yang digunakan dalam melakukan pre-test dan post-test adalah dengan menggunakan instrumen tes passing dan stopping 30 detik untuk mengukur hasil passing dan control. Populasi dalam penelitian ini adalah tim futsal di MAN 1 Jombang. Dari uji t menunjukkan bahwa data dari kelompok pretest kanan dan posttest kiri terdapat ada perbedaan atau ada pengaruh yang signifikan antara data masingmasing variabel, sedangkan kelompok pos test terdapat pengaruh pada passing pemain futsal MAN 1 Jombang dapat disimpulkan bahwa latihan kucing - kucngan berpengaruh yang signifikan terhadap kemampuan passing pemain fustal di MAN 1 Jombang.
\end{abstract}

\section{Abstract}

Futsal is one of the extracurricular that is quite popular. This is very helpful in facilitating and training students' skills in playing futsal outside of class hours. According to observations about the state of the players in futsal extracurriculars, many players still have poor abilities in passing balls, so when playing futsal there are still many students who have difficulty being able to play well. In this study, this type of research including experimental research. This experimental research uses the design "Pre-test and Post-test". The instrument in this study used a test measuring instrument used in pre-test and post-test is to use a 30 -second passing and stopping test instrument to measure the results of passing and control. The population in this study was the futsal team at MAN 1 Jombang. From the t test shows that the data from the right pretest group and the left posttest there is a difference or there is a significant influence between the data of each variable, while the posttest group has an influence on the passing of futsal players MAN 1 Jombang. Significant to the passing ability of fustal players in MAN 1 Jombang. 


\begin{tabular}{|c|c|c|}
\hline Journal STAND: Sports and Development & http://jurnal.unipasby.ac.id/index.php/stand/about/submissions \\
unipa Sumalay & jurnal.stand@unipasby.ac.id
\end{tabular}

\section{PENDAHULUAN}

Pembelajaran Olahraga adalah pembelajaran melalui aktivitas jasmani yang didesain untuk meningkatkan kebugaran jasmani, mengembangkan keterampilan motorik, pengetahuan dan perilaku hidup sehat dan aktif, sikap sportif, dan kecerdasan emosi. Dalam proses pembelajaran Pendidikan Jasmani guru diharapan mampu mengajarkan berbagai keterampilan gerak dasar, teknik dan strategi permainan/olahraga, internalisasi nilai-nilai seperti: sportivitas, jujur, kerjasama, disiplin, bertanggung jawab; dan pembiasaan hidup sehat, yang dalam pelaksanannya bukan melalui pengajaran konvensional di dalam kelas yang bersifat teoritis saja, namun melibatkan unsur fisik, mental intelektual, emosi dan sosial.

Futsal merupakan salah satu ekstrakurikuler yang cukup digemari. Hal ini sangat membantu dalam memfasilitasi dan melatih keterampilan siswa dalam bermain futsal di luar jam pelajaran. Menurut hasil observasi mengenai keadaan para pemain pada ekstrakurikuler futsal, banyak pemain yang masih memiliki kemampuan kurang baik dalam melakukan passing bola, sehingga ketika melakukan permainan futsal masih banyak siswa yang mengalami kesulitan untuk dapat bermain dengan baik. Berdasarkan pengamatan tersebut maka dalam hal ini penulis mengangkat sebuah permasalahan yang sekiranya bisa diselesaikan dalam waktu dekat untuk meningkatkan kualitas pada permainan futsal.
Dalam hal ini penulis ingin menerapkan modifikasi permainan dalam meningkatkan kemampuan passing bola pada ekstrakurikuler futsal yakni melalui permainan kucing kucingan bola. Metode permianan kucing bola yaitu suatu pendekatan pembelajaran yang lebih menekankan pada pembelajaran menarik, tanpa menghilangkan inti dari pembelajaran passing bola itu sendiri. Adapun langkah pemecahan masalah dari kegiatan tersebut adalah melakukan konsultasi dengan mentor, melakukan pretest, menyusun program latihan, dan mensosialisasikan materi terkait teknik passing bola. Langkah berikutnya, penulis melakukan latihan dan kemudian memberikan postest dan postes pada siswa. Sebagai CPNS di Madrasah Aliyah Negeri 1 Jombang penulis merasa perlu untuk segera memperbaiki permasalahan sesuai bidangnya yaitu sebagai guru pendidikan jasmani dan sebagai pembina ekstrakurikuler futsal. Sehingga bisa memberikan kontribusi secara maksimal kepada Madrasah, khususnya di bidang pendidikan jasmani dan sebagai seorang Aparatur Sipil Negara yang memiliki tanggung jawab besar terhadap pendidikan di Indonesia.

\section{KAJIAN LITERATUR}

Menurut Justinus Lhaksana, (2011: 5) futsal (futbol sala) dalam bahasa Spanyol berarti sepak bola dalam ruangan merupakan permainan sepak bola yang di lakukan di dalam ruangan. Permainan ini sendiri di lakukan oleh lima pemain setiap tim berbeda sepak bola konvensional yang pemainnya berjumlah sebelas

Volume 1 Nomor 1 Tahun 2020 | 57 


\begin{tabular}{|c|c|c|}
\hline unima Sumalaya & $\begin{array}{c}\text { Journal STAND: Sports and Development } \\
\text { http://jurnal.unipasby.ac.id/index.php/stand/about/submissions } \\
\text { jurnal.stand@unipasby.ac.id }\end{array}$ \\
\hline
\end{tabular}

orang setiap tim. Futsal adalah permainan bola yang dimainkan oleh dua tim, yang masingmasing beranggotakan lima orang. Tujuannya adalah memasukkan bola ke gawang lawan, dengan memanipulasi bola dengan kaki. Selain lima pemain utama, setiap regu juga diizinkan memiliki pemain cadangan. Tidak seperti permainan sepakbola dalam ruangan lainnya, lapangan futsal dibatasi garis, bukan net atau papan.

Menurut Sugono (2008:401), futsal adalah olahraga permainan sepakbola, dengan lapangan dan gawang lebih kecil, biasanya dimainkan di dalam ruangan besar, masing-masing tim terdiri atas lima orang. Yudianto (2009:54), futsal adalah permainan jenis sepakbola yang dimainkan oleh 10 orang (masing-masing 5 orang), serta menggunakan bola lebih kecil dan lebih berat daripada yang digunakan dalam sepakbola. Gawang yang digunakan dalam futsal juga lebih kecil.

Menurut Kurniawan (2012:104), futsal adalah permainan bola yang dimainkan oleh dua tim, yang masing-masing tim beranggotakan lima orang dengan tujuan untuk memasukkan bola ke gawang lawan, dengan manipulasi bola dan kaki.

Rondo atau dikenal juga dengan istilah kucing-kucingan adalah sebuah metode untuk meningkatkan kemampuan passing yang diimplementasikan pada seluruh level pemain sepakbola dalam jurnal Ilmiah Pendidikan Jasmani, 3 (1) 2019. Menurut Johan Cruyff dalam buku Our Competition is the World, rondo atau kucing-kucingan memasukkan hampir semua aspek dalam permainan sepak bola kecuali shooting. Rondo atau yang biasa dikenal dengan istilah kucing-kucingan, permainan ini ternyata sangatlah efektif untuk meningkatkan chemestry dan juga teknik sebuah tim.

\section{a. Metode Latihan Rondo (Kucing- Kucingan)}

Rondo merupakan bentuk latihan dengan skema lingkaran diisi beberapa pemain dan menempatkan satu atau dua pemain di tengah lingkaran. Dalam artikel M. Husen (2015), Bentuk latihannya yaitu para pemain yang berdiri di keliling lingkaran harus berusaha untuk terus menguasai bola dengan cara mengumpankan bola satu sama lain. Sebaliknya, pemain yang berada di tengah lingkaran harus berusaha untuk memotong bola.

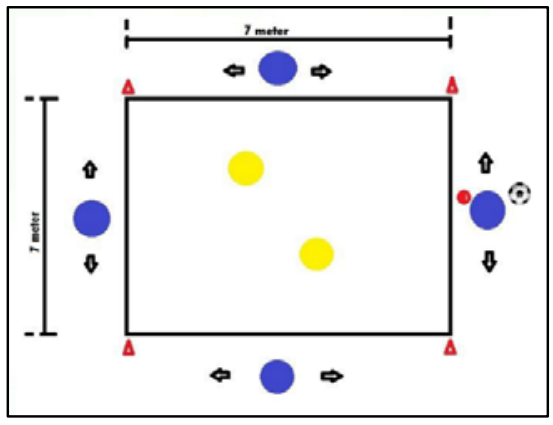

Gambar 1. Metode 4-2 kucing - kucingan Box passing dril.

\section{METODE PENELITIAN}

Penelitian ini termasuk jenis penelitian eksperimen. Sugiyono (2009:107) menyatakan bahwa penelitian eksperimen merupakan penelitian untuk mencari pengaruh perlakuan tertentu terhadap kondisi yang terkendali. Pada 


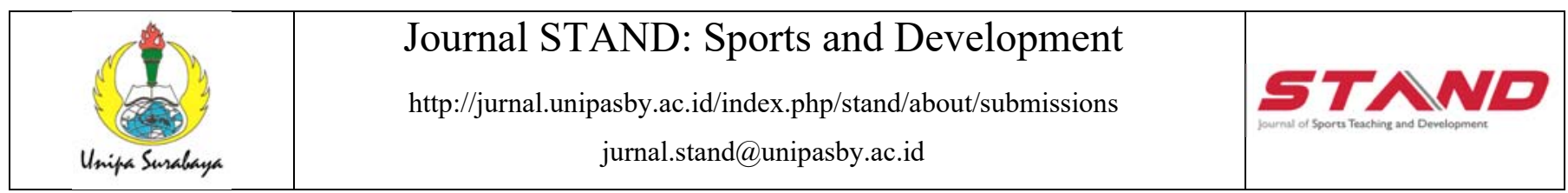

penelitian ini, pengaruh yang dilihat adalah pengaruh latihan kucing - kucingan terhadap peningkatan passing.

Salah satu tugas penting dalam penelitian adalah menetapkan ada tidaknya hubungan sebab akibat antara fenomena-fenomena dan menarik hukum-hukum tentang hubungan sebab akibat itu. Penelitian eksperimen adalah suatu penelitian yang selalu dilakukan dengan maksud untuk melihat akibat dari suatu perlakuan yang telah diberikan dalam waktu tertentu (Arikunto, 2010:9). Penelitian eksperimen ini menggunakan desain "Pre-test dan Post-test".

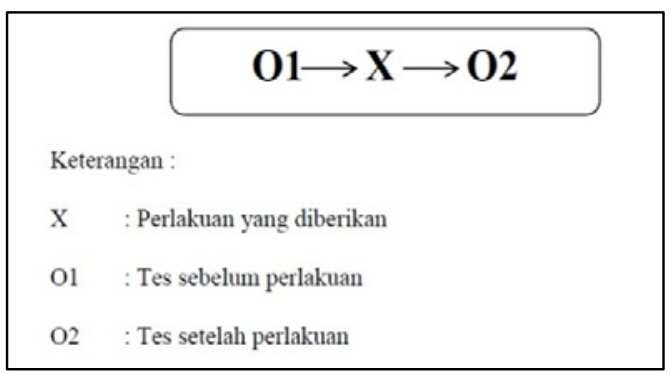

(sumber: Arikunto, 2010:9)

Instrumen penelitian adalah alat ukur yang digunakan dalam pengumpulan data (Maksum, 2012). Adapun alat ukur tes yang digunakan dalam melakukan pre-test dan post-test adalah dengan menggunakan instrumen tes passing dan stopping 30 detik untuk mengukur hasil passing dan control. Nurhasan, (2000: 150).

Tes ini mengukur kecakapan dan keterampilan passing dan control dan dapat digunakan untuk mengelompokkan pemain, juda dapat diergunakan sebagai dasar pemberian nilai pendidikan olahraga di sekolah.

Petunjuk pelaksanaan tes passing dan stopping:
Tujuan:

Mengukur keterampilan dan gerak kaki dalam menyepak dan menahan bola.

Alat yang digunakan:

1. Bola 2 buah

2. Stop Wacth

3. Bangku swedia 4 buah (papan ukuran 3 $\mathrm{m}$ x $60 \mathrm{~cm}$ sebanyak 2 buah)

4. Kapur

Petunjuk pelaksanaan tes:

1. Testee berdiri dibelakang garis tembak yang berjarak 4 meter dari sasaran papan, bleh dengan posisi kanan siap menembak ataupun sebaliknya.

2. Ada aba aba "Ya" testee mulai menyepak bola ke sasaran/papan dan menahanya kembali dengan kaki dibelakang garis tembak kaki yang akan menyepak bola berikutnya yang arahnya berlawanan dengan seakan pertama

3. Lakukan kegiatan ini bergantian antara kaki kiri dan kanan selama 30 detik

4. Apabila bola keluar dari daerah sepak, maka testee menggunakan bola cadangan yang telah di sediakan.

Gerakan tersebut dinyatakan gagal bila:

1. Bola ditahan dan disepak di depan garis sepak yang akan menyepak bola.

2. Hanya menahan dan menyepak bola dengan satu kaki saja

\section{Hasil dan Pembahasan}

Data yang diperoleh berupa data hasil tes Passing Terhadap Peningkatan passing Pemain Futsal Di MAN 1 Jombang sebagai berikut: 


\begin{tabular}{|c|c|}
\hline Journal STAND: Sports and Development \\
unipa Sumalama
\end{tabular} $\begin{gathered}\text { htt//jurnal.unipasby.ac.id/index.php/stand/about/submissions } \\
\text { jurnal.stand@unipasby.ac.id }\end{gathered}$

Berdasarkan data pada, maka dapat disimpulkan bahwa hasil uji homogenitas diperoleh nilai signifikan semua lebih besar dari p-value 0.05, maka data berdisitribusi homoogen. Hal ini menunjukan syarat untuk uji t bisa di lanjutkan.

Table. Paired Differences

\begin{tabular}{rrrlll}
\hline $\begin{array}{c}\text { Std. } \\
\text { Mean }\end{array}$ & $\begin{array}{c}\text { Std. } \\
\text { Deviatio } \\
\mathrm{n}\end{array}$ & $\begin{array}{c}\text { Error } \\
\text { Mean }\end{array}$ & $\mathrm{t}$ & df & Sig \\
\hline 46.50 & 46.4842 & 10.3942 & & & \\
000 & 9 & 0 & -4.474 & 19 & .000 \\
\hline
\end{tabular}

Berdasarkan dari table di atas, menunjukkan bahwa data dari kelompok pre test kanan dan post test kiri terdapat ada perbedaan atau ada pengaruh yang signifikan antara data masing-masing variabel, sedangkan kelompok pos test kanan dan pos test kiri terdapat pengaruh pada passing pemain futsal MAN 1 Jombang.

\section{Pembahasan}

Perkembangan olahraga pada saat ini berkembang sangat cepat sesuai dengan perkembangan jaman. Perkembangan jaman berpengaruh terhadap munculnya cabang olahraga baru yang diantaranya adalah futsal. Beberapa hal pendukung yang diperlukan dalam futsal adalah Passing dan Control. Salah satu dalam pendukung futsal adalah Passing dan Control. Dimana Passing dan Control adalah salah satu faktor terpenting dalam futsal karena dengan Passing dan Control kita dapat bermain futsal dengan baik dan dapatkan menciptakan suatu keberhasilan dalam mencetak gol.

Perlu diketahui bahwa pelaksanaan futsal melalui pelatihan teknik, sebab teknik dan fisik adalah salah satu kesatuan utuh dari komponenkomponen yang tidak dapat dipisahkan begitu saja, baik peningkatan maupun pemeliharaannya. Artinya bahwa di dalam usaha-usaha peningkatan kondisi fisik maka seluruh komponen harus dikembangkan, walaupun disana-sini dilakukan dengan sistem prioritas, sesuai dengan keadaan atau status tiap komponen tersebut.

Latihan kucing - kucingan ini juga mengajarkan pemain untuk mengambil langkahlangkah yang tepat dengan menggunakan Passing dan Control yang dimiliki. Latihan salah satu variasi latihan dari sekian banyak variasi yang ada (Hadi dkk, 2016). Variasi yang ada dalam bentuk latihan teknik disertai keterampilan gerak yang fungsinya melatih Passing dan Control kaki dan sinkronisasi gerak secara seimbang (Reynolds, 2011 online).

Menurut Sucipto dkk. (2000:17) passing adalah salah satu tujuan dari menendang bola. Menendang bola dilihat dari perkenaan bagian kaki ke bola, menendang dibedakan beberapa macam, yaitu menendang dengan kaki bagan dalam (inside), kaki bagian luar (outside), punggung kaki (instep), dan punggung kaki bagian dalam (inside of the instep). Akan tetapi dalam sebuah tim, Passing dan Control sangat jarang diberikan oleh pelatih ekstrakurikuler dalam latihan apabila suatu tim tidak mempunyai waktu dalam melatih dan persiapan jangka panjang. Pada saat berlatih, menu latihan Passing dan Control terlihat sangat jarang dan hanya sedikit diberikan oleh pelatih. Hal ini 


\begin{tabular}{|c|c|}
\hline Journal STAND: Sports and Development \\
unipa Sumalama
\end{tabular} $\begin{gathered}\text { htt//jurnal.unipasby.ac.id/index.php/stand/about/submissions } \\
\text { jurnal.stand@unipasby.ac.id }\end{gathered}$

dikarenakan pelatih lebih condong hanya untuk membentuk game tim yang solid. Pada kenyataannya, Passing dan Control juga perlu dan sangat dibutuhkan pada saat bermain untuk menghadapai lawanlawan yang mempunyai kualitas lebih bagus. Untuk itu perlu latihan tambahan di luar lapangan yang dapat meningkatkan Passing dan Control pemain.

Melakukan Passing dan Control secara berulang-ulang seperti halnya kucing - kucingan memerlukan kontraksi secara bergantian pada kelompok tertentu Sebagai contoh seseorang yang akan melakukan rondo atau kucing kucingan harus menambah Passing dan Control pada waktu luang, untuk itu teknik Passing dan Control mengalami peningkatan dalam bermain futsal.

Passing dan Control yang dilakukan oleh pemain futsal saat berlatih maupun bertanding tergantung pula oleh kemampuan mengkoordinasi sistem gerak tubuh dengan respon terhadap situasi dan kondisi yang dihadapi. Passing dan Control ditentukan oleh faktor kecepatan bereaksi, kemampuan untuk menguasai situasi dan mampu mengendalikan gerakan secara tibatiba. Kegunaan Passing dan Control sangat penting terutama olahraga futsal dan memerlukan ketangkasan, khususnya futsal. Menurut Scheunemann, T (2005:33) memiliki passing yang akurat adalah harga mati bagi seorang pemain sepakbola. Mengingat passing begitu sering dilakukan dalam sebuah pertandingan, pelatih yang baik akan memulai tugasnya dengan memperbaiki kemampuan passing para pemainnya Adapun faktor-faktor yang mempengaruhi Passing dan Control.

Dari beberapa definisi yang telah diuraikan dapat disimpulkan bahwa Passing dan Control adalah kemampuan seseorang dalam melakukan tendangan dan menerima bola untuk mengumpan kepada teman satu tim dengan tujuan mengahsilkan permainan yang bagus untk mencitakan sebuah peluang dalam menciptakan goal untuk mendapatkan kemenangan.

\section{KESIMPULAN}

Berdasarkan pengujian hipotesis dan pembahasan dalam penelitian yang dilakukan, maka diperoleh hasil penelitian yang dapat disimpulkan: Bahwa latihan kucing - kucingan berpengaruh yang signifikan terhadap kemampuan passing pemain fustal di MAN 1 Jombang.

Terdapat rata-rata pretest kanan 36,23 sedangkan postest kiri 38,36 setelah di berikan perlakuan, sedangkan pos test kanan 36,36 dan pos test kiri 38,53 setelah diberikan perlakuan

\section{REFERENSI}

Charlim, (2011). Mengenal lebih jauh tentang futsal. Jakarta: Multi Kreasi satu delapan diakses Pada Pukul 19:00, hari rabu tanggal 30/08/2019).

Girard, O., Villanueva, A.M., Bishop, D.J. (2011). Repeated Sprint Ability-Part II: Recommendation for Training, Sports Medicine, 41(8), 673-94. 


\begin{tabular}{|c|c|}
\hline Journal STAND: Sports and Development \\
unipa Sunalaya
\end{tabular} $\begin{gathered}\text { http://jurnal.unipasby.ac.id/index.php/stand/about/submissions } \\
\text { jurnal.stand@unipasby.ac.id }\end{gathered}$

Kusnanik, N.W. dan Rattray Ben. Effect of Ladder Speed Run and Repeatd Sprint Ability In Improving Agility and Speed of Junior Soccer Players. Acta Kinesiologica. 11 (2017) issue 1:19-22.

McKeag, D. dan Moeller, B., \& James, L. (2007). ACSM's Primary Care Sports Medicine (second edition). Philadelphia: NAPCO Media.

Husen, M. 2015. Pengaruh metode latihan el rondo dan circle passing drill terhadap ketepatan passing sepakbola siswa SSB Bhaladika. Skripsi. Jurusan PKLO Fakultas Ilmu Keolahragaan Universitas Negeri Semarang.

M, Sajoto. 1998. Peningkatan dan Pembinaan Kekuatan Kondisi Fisik Dalam Olahraga. Semarang: Dahara Prize

Mielke, D. 2004. Dasar-Dasar Sepak Bola. Jakarta : Pakar Raya.

Rubiant Hadi. 2007. Ilmu Kepelatihan Dasar. Semarang: CV Cipta Prima Nusantara.

Scheunemann, T. 2005. Dasar-Dasar Sepak Bola Modern. Malang: Dioma.

Sugianto, dan Restu Ilahi B, \& Defliyanto. 2019. Implementasi Metode Rondo Untuk Meningkatkan Teknik Passing Mahasiswa Pada Mata Kuliah Futsal Penjas Prodi Penjas FKIP Unib. Jurnal Ilmiah Pendidikan Jasmani, 3 (1) 2019.

Sucipto, dkk, 2000. Sepakbola Departemen Pendidikan Dan Kebudayaan: Direktorat Jenderal Pendidikan dan Kebudayaan. www.fifa.com, diakses pada pukul 19:00, hari rabu tanggal 30/08/2019). 